\title{
Mortality Among Patients Admitted in a Psychiatric Facility: A Single-Centre Review
}

\author{
Mark Mohan Kaggwa (iD \\ Sarah Maria Najjuka (iD) ${ }^{2}$ \\ Sheila Harms ${ }^{1,3}$ \\ Scholastic Ashaba (iD) \\ 'Department of Psychiatry, Faculty of \\ Medicine, Mbarara University of Science \\ and Technology, Mbarara, Uganda; \\ ${ }^{2}$ Makerere University, College of Health \\ Sciences, Kampala, Uganda; ${ }^{3}$ Department \\ of Psychiatry \& Behavioural \\ Neurosciences, McMaster University, \\ Hamilton, Ontario, Canada
}

Background: There is higher global mortality among persons living with mental illness than the general population, attributed to the risky behaviours associated with mental illness, medical comorbidities, or side effects of psychiatric medications that result in premature death among psychiatric in patients.

Objective: This audit aimed to describe the characteristics of patients with mental illness who died during admission at a tertiary psychiatric ward in Uganda.

Methods: This was a retrospective chart review of patients who died while admitted to a psychiatry ward between January 1995 to July 2020.

Results: We reviewed 30 charts, of which 18 (60\%) patients were women. The majority of patients died during 2002 (13.3\%). Many were diagnosed with a brief psychotic disorder, 7 (23.3\%), followed by bipolar disorder $6(20.0 \%)$. HIV and epilepsy were the most common comorbidities. The majority of the death causes of death were unknown, 20 (66.7), but heart attack ( $n=2)$ was the most identified cause.

Conclusion: The majority of the causes of mortality were unknown. The most common cause of mortality was heart attack, a common effect of metabolic disease and chronic antipsychotic use. Mortality audits are warranted to identify possible causes and to develop strategic interventions for mortality prevention.

Keywords: mortality, audit, psychiatric inpatients, suicide, antipsychotic medications, medical comorbidities, HIV/AIDS, hospitalization, mental health, epilepsy, continued care

\section{Introduction}

Mortality among patients with mental illness is higher than that among the general population, although the causes of mortality are not usually related to mental illness. ${ }^{1}$ The mortality rate is 2.2 times higher among patients with psychotic disorders in the community receiving outpatient care than the general population. ${ }^{1}$ Mortality among in patients with mental illness is higher than that among outpatients, mainly due to the fact that in patients tend to have advanced psychiatric conditions and more poor medical comorbidities than outpatients. ${ }^{1,2}$

Overall, people with a history of psychiatric hospitalization have a high risk of premature death, attributed to the severity of the disorder and length of exposure to psychiatric medicines. ${ }^{3}$ Prolonged exposure to psychiatric medications and their adverse effects lead to poor health and predispose patients to comorbidities such as diabetes, cardiovascular diseases (CVD), and hypertension, which contribute to high mortality among people with mental illness. ${ }^{4,5}$ Moreover, these patients commonly engage in high-risk behaviours such as tobacco smoking, alcohol and illicit drug use, physical inactivity, and improper diet; which increases their risk of medical
Correspondence: Mark Mohan Kaggwa Email kmarkmohan@gmail.com 
Table I Characteristics of the Patients Who Died During Admission

\begin{tabular}{|c|c|c|c|c|c|c|c|c|c|c|}
\hline Record & $\begin{array}{l}\text { Year } \\
\text { of } \\
\text { Death }\end{array}$ & $\begin{array}{l}\text { Years } \\
\text { with } \\
\text { Mental } \\
\text { Illness }\end{array}$ & $\begin{array}{l}\text { Age } \\
\text { at } \\
\text { Time } \\
\text { of } \\
\text { Death }\end{array}$ & Sex & Diagnosis & $\begin{array}{l}\text { Differential } \\
\text { Diagnosis }\end{array}$ & $\begin{array}{l}\text { Number } \\
\text { of Days } \\
\text { on Ward }\end{array}$ & $\begin{array}{l}\text { Number } \\
\text { of } \\
\text { Reviews } \\
\text { per Day }\end{array}$ & $\begin{array}{l}\text { EPS } \\
\text { Presence }\end{array}$ & $\begin{array}{l}\text { Consultation } \\
\text { Liaison }\end{array}$ \\
\hline I & 2020 & 0 & 82 & $\mathrm{~F}$ & BPD & Delirium & 2 & 3.00 & Yes & No \\
\hline 2 & 2019 & 0 & 34 & $M$ & BPD & $\begin{array}{l}\text { BPD, Arthritis, } \\
\text { Disseminated TB }\end{array}$ & 3 & 3.30 & No & Yes \\
\hline 3 & 2019 & 0 & 42 & $M$ & $\begin{array}{l}\text { HIV induced } \\
\text { mental illness }\end{array}$ & - & 2 & 1.50 & No & No \\
\hline 4 & 2018 & 3 & 50 & $\mathrm{~F}$ & Headache & SUD & I & 6.00 & No & No \\
\hline 5 & 2016 & 7 & 54 & $\mathrm{~F}$ & Depression & - & 2 & 1.00 & No & No \\
\hline 6 & 2016 & 23 & 46 & $\mathrm{~F}$ & BAD & - & 2 & 1.50 & Yes & No \\
\hline 7 & 2015 & 0 & 15 & M & BPD & - & 3 & 1.30 & No & No \\
\hline 8 & 2014 & 0 & 24 & $\mathrm{~F}$ & Delirium & - & 2 & 1.00 & No & No \\
\hline 9 & 2014 & 3 & 38 & $F$ & BAD & Schizophrenia & 3 & 0.60 & No & No \\
\hline 10 & 2014 & 20 & 52 & $F$ & Schizophrenia & - & 4 & 0.75 & No & No \\
\hline 11 & 2013 & 0 & 50 & M & Schizophrenia & SUD & 6 & 0.00 & No & No \\
\hline 12 & 2012 & 0 & 30 & $M$ & Epilepsy & - & 120 & 0.20 & No & No \\
\hline 13 & 2012 & 20 & 62 & M & BAD & - & 2 & 1.00 & Yes & No \\
\hline 14 & 2011 & 0 & 47 & $M$ & $\begin{array}{l}\text { Severe } \\
\text { diarrhea }\end{array}$ & $\begin{array}{l}\text { PML, } \\
\text { Toxoplasmosis, } \\
\text { Cryptosporidiosis }\end{array}$ & 5 & 1.00 & No & Yes \\
\hline 15 & 2010 & 10 & 70 & $\mathrm{~F}$ & BAD & EPS & 3 & 0.60 & Yes & No \\
\hline 16 & 2010 & 19 & 61 & $F$ & Schizophrenia & BAD & 19 & 0.40 & No & No \\
\hline 17 & 2009 & 0 & 80 & M & Pneumonia & $\begin{array}{l}\text { Delirium, BAD, } \\
\text { Dementia }\end{array}$ & 7 & 1.10 & Yes & Yes \\
\hline
\end{tabular}




\begin{tabular}{|c|c|c|c|c|c|c|c|c|c|c|}
\hline Record & Investigations & $\begin{array}{l}\text { History } \\
\text { of } \\
\text { Mental } \\
\text { Illness }\end{array}$ & $\begin{array}{l}\text { Family } \\
\text { History } \\
\text { of } \\
\text { Mental } \\
\text { Illness }\end{array}$ & $\begin{array}{l}\text { History of } \\
\text { Substance } \\
\text { Abuse }\end{array}$ & Comorbidities & $\begin{array}{l}\text { History of } \\
\text { Attempted } \\
\text { Suicide }\end{array}$ & $\begin{array}{l}\text { History } \\
\text { of } \\
\text { physical } \\
\text { Trauma }\end{array}$ & $\begin{array}{l}\text { Time } \\
\text { of } \\
\text { Death }\end{array}$ & $\begin{array}{l}\text { Possible Cause of } \\
\text { Death }\end{array}$ & $\begin{array}{l}\text { Medications } \\
\text { Used }\end{array}$ \\
\hline 1 & - & No & Yes & No & - & No & No & $\mathrm{N}$ & - & $\begin{array}{l}\text { Chlorpromazine, } \\
\text { Haloperidol, } \\
\text { Diazepam }\end{array}$ \\
\hline 2 & Normal & Yes & No & No & TB, Epilepsy & No & Yes & $N$ & TB & \\
\hline 3 & - & No & No & Yes & HIV & No & No & $\mathrm{N}$ & - & $\begin{array}{l}\text { Haloperidol, } \\
\text { Carbamazepine }\end{array}$ \\
\hline 4 & - & No & No & Yes & - & No & No & $\mathrm{E}$ & - & $\begin{array}{l}\text { Haloperidol, } \\
\text { Diazepam, } \\
\text { Amitriptyline }\end{array}$ \\
\hline 5 & - & Yes & Yes & No & - & Yes & No & $\mathrm{E}$ & - & $\begin{array}{l}\text { Chlorpromazine, } \\
\text { Diazepam }\end{array}$ \\
\hline 6 & Normal & Yes & No & No & - & No & Yes & $\mathrm{D}$ & TBI & $\begin{array}{l}\text { Chlorpromazine, } \\
\text { Diazepam }\end{array}$ \\
\hline 7 & - & No & No & No & - & No & No & $\mathrm{N}$ & - & $\begin{array}{l}\text { Chlorpromazine, } \\
\text { Diazepam }\end{array}$ \\
\hline 8 & - & No & No & No & $\begin{array}{l}\text { Cerebral, } \\
\text { Malaria }\end{array}$ & No & No & $\mathrm{N}$ & Cerebral Malaria & $\begin{array}{l}\text { Chlorpromazine, } \\
\text { Haloperidol, } \\
\text { Diazepam }\end{array}$ \\
\hline 9 & - & Yes & No & No & - & No & No & D & *Heart attack & $\begin{array}{l}\text { Haloperidol, } \\
\text { Carbamazepine, } \\
\text { Amitriptyline }\end{array}$ \\
\hline 10 & - & Yes & No & No & - & No & No & $N$ & - & $\begin{array}{l}\text { Haloperidol, } \\
\text { fluphenazine }\end{array}$ \\
\hline 11 & Normal & No & No & Yes & - & No & No & $\mathrm{N}$ & - & \\
\hline 12 & - & No & No & No & Epilepsy & No & Yes & $N$ & - & $\begin{array}{l}\text { Haloperidol, } \\
\text { Phenobarbital }\end{array}$ \\
\hline 13 & Normal & Yes & No & No & - & No & No & $\mathrm{N}$ & *Heart attack & $\begin{array}{l}\text { Chlorpromazine, } \\
\text { Haloperidol, } \\
\text { Carbamazepine, } \\
\text { Diazepam, } \\
\text { Amitriptyline }\end{array}$ \\
\hline 14 & - & No & No & No & HIV & No & No & D & Severe diarrhea & $\begin{array}{l}\text { Haloperidol, } \\
\text { Diazepam, } \\
\text { Ceftriaxoneotics }\end{array}$ \\
\hline 15 & - & Yes & Yes & No & - & No & No & $\mathrm{E}$ & - & $\begin{array}{l}\text { Carbamazepine, } \\
\text { Diazepam }\end{array}$ \\
\hline 16 & - & Yes & No & No & - & No & No & $\mathrm{E}$ & - & $\begin{array}{l}\text { Haloperidol, } \\
\text { Diazepam }\end{array}$ \\
\hline 17 & - & Yes & Yes & Yes & - & No & No & $D$ & $\begin{array}{l}\text { Aspiration } \\
\text { pneumonia }\end{array}$ & $\begin{array}{l}\text { Chlorpromazine, } \\
\text { Diazepam }\end{array}$ \\
\hline
\end{tabular}

(Continued) 
Table I (Continued).

\begin{tabular}{|c|c|c|c|c|c|c|c|c|c|c|}
\hline Record & $\begin{array}{l}\text { Year } \\
\text { of } \\
\text { Death }\end{array}$ & $\begin{array}{l}\text { Years } \\
\text { with } \\
\text { Mental } \\
\text { Illness }\end{array}$ & $\begin{array}{l}\text { Age } \\
\text { at } \\
\text { Time } \\
\text { of } \\
\text { Death }\end{array}$ & Sex & Diagnosis & $\begin{array}{l}\text { Differential } \\
\text { Diagnosis }\end{array}$ & $\begin{array}{l}\text { Number } \\
\text { of Days } \\
\text { on Ward }\end{array}$ & $\begin{array}{l}\text { Number } \\
\text { of } \\
\text { Reviews } \\
\text { per Day }\end{array}$ & $\begin{array}{l}\text { EPS } \\
\text { Presence }\end{array}$ & $\begin{array}{l}\text { Consultation } \\
\text { Liaison }\end{array}$ \\
\hline 18 & 2009 & 0 & 50 & $\mathrm{~F}$ & Diabetes & $\begin{array}{l}\text { Epilepsy, } \\
\text { Diabetes, } \\
\text { Poisoning, SUD }\end{array}$ & 3 & 1.00 & No & Yes \\
\hline 19 & 2008 & 0 & 50 & $\mathrm{~F}$ & Schizophrenia & BAD & 7 & 1.00 & No & No \\
\hline 20 & 2007 & 0 & 50 & $\mathrm{~F}$ & Delirium & $\mathrm{BPD}$ & 4 & 0.30 & No & No \\
\hline 21 & 2006 & 30 & 86 & M & BAD & $\begin{array}{l}\text { Malignancy, } \\
\text { Infection, } \\
\text { Hypoglycemia }\end{array}$ & 1 & 1.00 & No & Yes \\
\hline 22 & 2005 & 0 & 35 & $\mathrm{~F}$ & $\mathrm{BPD}$ & Delirium & 2 & 2.50 & Yes & Yes \\
\hline 23 & 2005 & 0 & 70 & M & Depression & - & 6 & 0.70 & No & No \\
\hline 24 & 2004 & 20 & 63 & $\mathrm{~F}$ & $\mathrm{BPD}$ & - & 4 & 1.50 & Yes & No \\
\hline 25 & 2002 & 0 & 50 & $\mathrm{~F}$ & BAD & $\begin{array}{l}\text { Delirium, } \\
\text { schizophrenia }\end{array}$ & 33 & 0.30 & No & No \\
\hline 26 & 2002 & 0 & 32 & M & Pneumonia & $\begin{array}{l}\text { BPD, Pneumonia, } \\
\text { Depression }\end{array}$ & 27 & 0.70 & Yes & Yes \\
\hline 27 & 2002 & 0 & 35 & $M$ & $\begin{array}{l}\text { HIV induced } \\
\text { mental illness }\end{array}$ & $\begin{array}{l}\text { HIV induced } \\
\text { mental } \\
\text { illness, } \\
\text { Toxoplasmosis, } \\
\text { Cryptosporidiosis, } \\
\text { Dementia }\end{array}$ & 2 & 2.50 & No & Yes \\
\hline 28 & 2002 & 0 & 50 & $\mathrm{~F}$ & $\mathrm{BPD}$ & BPD & 7 & 1.00 & Yes & Yes \\
\hline 29 & 2000 & 0 & 25 & $\mathrm{~F}$ & Delirium & - & 2 & 1.00 & No & No \\
\hline 30 & 2000 & 1 & 32 & $\mathrm{~F}$ & $\begin{array}{l}\text { HIV induced } \\
\text { mental illness }\end{array}$ & $\begin{array}{l}\text { BPD, TB, Diabetes, } \\
\text { Vaginal candidiasis }\end{array}$ & 6 & 1.70 & No & Yes \\
\hline
\end{tabular}

Note: *Postmortem findings.

Abbreviations: F, female; M, male; BPD, brief psychotic disorder; BAD, bipolar affective disorder; TB, tuberculosis; SUD, substance use disorder; EPS, extrapyramidal side effects; N, night; E, evening; D, day; TBI, traumatic brain injury.

comorbidities, including CVD, diabetes, and infections. ${ }^{6-8}$ Comorbidities, preventable with lifestyle changes, are associated with higher levels of mortality. ${ }^{4,5}$ However, lifestyle changes are challenging among patients, given the symptoms of mental illness and the side effects of medicines such as day time sedation and general weakness that limit their ability to make realistic plans and goals and follow them. ${ }^{6,7}$
Despite numerous studies showing that patients with mental illness are at a higher risk of mortality compared to the general population, information on inpatient mortality among patients admitted to psychiatry hospitals in Uganda. We conducted a retrospective chart review of patients who died while admitted to the psychiatry ward at a tertiary hospital in southwestern Uganda to identify the common characteristics of these patients. 


\begin{tabular}{|c|c|c|c|c|c|c|c|c|c|c|}
\hline Record & Investigations & $\begin{array}{l}\text { History } \\
\text { of } \\
\text { Mental } \\
\text { Illness }\end{array}$ & $\begin{array}{l}\text { Family } \\
\text { History } \\
\text { of } \\
\text { Mental } \\
\text { Illness }\end{array}$ & $\begin{array}{l}\text { History of } \\
\text { Substance } \\
\text { Abuse }\end{array}$ & Comorbidities & $\begin{array}{l}\text { History of } \\
\text { Attempted } \\
\text { Suicide }\end{array}$ & $\begin{array}{l}\text { History } \\
\text { of } \\
\text { physical } \\
\text { Trauma }\end{array}$ & $\begin{array}{l}\text { Time } \\
\text { of } \\
\text { Death }\end{array}$ & $\begin{array}{l}\text { Possible Cause of } \\
\text { Death }\end{array}$ & $\begin{array}{l}\text { Medications } \\
\text { Used }\end{array}$ \\
\hline 18 & Abnormal & No & No & No & Diabetes & No & No & N & Hypoglycemia & Phenytoin, IV fluids \\
\hline 19 & - & Yes & Yes & No & - & No & No & N & - & $\begin{array}{l}\text { Chlorpromazine, } \\
\text { Diazepam }\end{array}$ \\
\hline 20 & - & No & No & No & - & No & No & D & - & $\begin{array}{l}\text { Haloperidol, } \\
\text { Diazepam }\end{array}$ \\
\hline 21 & Abnormal & Yes & Yes & No & - & Yes & No & D & *Thromboembolism & Haloperidol \\
\hline 22 & Normal & No & No & Yes & - & No & No & N & - & $\begin{array}{l}\text { Chlorpromazine, } \\
\text { Haloperidol, } \\
\text { Diazepam }\end{array}$ \\
\hline 23 & - & Yes & No & No & - & No & No & D & - & Amitriptyline \\
\hline 24 & - & Yes & No & No & - & No & No & N & - & $\begin{array}{l}\text { Haloperidol, } \\
\text { Thiodazine, } \\
\text { Diazepam }\end{array}$ \\
\hline 25 & Abnormal & No & No & No & - & No & No & D & - & Chlorpromazine \\
\hline 26 & Abnormal & No & No & No & Pneumonia & No & Yes & D & $\begin{array}{l}\text { Respiratory distress } \\
\text { syndrome }\end{array}$ & Chlorpromazine \\
\hline 27 & - & No & No & No & HIV & No & No & $\mathrm{N}$ & - & $\begin{array}{l}\text { Chlorpromazine, } \\
\text { Haloperidol }\end{array}$ \\
\hline 28 & Normal & No & No & No & Epilepsy & No & No & $\mathrm{N}$ & - & Chlorpromazine \\
\hline 29 & - & No & No & No & - & No & No & D & - & Chlorpromazine \\
\hline 30 & Abnormal & Yes & Yes & No & HIV & No & No & N & - & Chlorpromazine \\
\hline
\end{tabular}

\section{Methods}

This was a retrospective chart review of patients who died while admitted to the psychiatry ward of Mbarara Regional Referral Hospital between January 1995 and July 2020.

Using the inpatient record book that records the outcomes of the patients, we traced files of the patients who died while on the ward during the stated duration and retrieved the files from the records office. A careful chart review of the clinical notes was performed independently by two trained research assistants using a pretested data extraction tool. Data about age, sex, diagnosis, number of clinical reviews per day, number of days in the ward, presence of extrapyramidal side effects, investigation outcomes, prior history of mental illness, family history of mental illness, number of years with mental illness, medical comorbidities, history of attempted suicide, medications prescribed, history of physical trauma, 
time of death, and cause of death were collected. Data were entered parallel by two investigators (MMK and SMN) in a pretested web-based Google form. In case of discrepancies in data entry, the two data entrants had to discuss them with the SA. The Microsoft Excel sheet of the data entered in the Google form was downloaded and checked for completeness and errors by SMN.

\section{Results}

We retrieved 43 records from the report book, and 13 were excluded due to missing records $(n=8)$ and incomplete data $(n=5)$.

Over the 25-year period, mortality remained almost constant, with most deaths occurring in 2002 (Table 1). The deceased were aged 15-52 years, only 12 were male, 7 (23.3\%) had a family history of mental illness, 14 (46.7\%) had a positive history of mental illness, and the years lived with mental illness ranging from 0 to 30 . The majority of the deceased were diagnosed with brief psychotic disorder, 7 (23.3\%), followed by bipolar disorder 6 (20.0\%). HIV and epilepsy were the most common comorbidities. The majority of the deceased spent two days in the ward. They were reviewed 0 to 6 times a day, $10(33.3 \%)$ were reviewed by the consultation-liaison team, $11(26.7 \%)$ had investigations performed, and six were normal. Most of the deceased were on antipsychotics $25(83.3 \%)$ and diazepam $15(50.0 \%)$. The majority of deaths, 20 (66.7\%), had unknown causes of death, with only three postmortem reports available in the data to confirm the causes of death (Supplementary file 1). The most common cause of death was heart attacks.

\section{Discussion}

Death among patients admitted to the psychiatry ward is no longer rare. In this study, mortality became a prevalent event in the psychiatric inpatient ward over the 25 years, with a minimum of two deaths every two years since 2000 . Higher incidences were observed in the early 2000s. This may be attributed to the increasing number of patients requiring inpatient mental health care following an increased prevalence of medical conditions presenting with mental illness symptoms such as HIV/AIDS. HIV/ AIDS is one of the most prevalent conditions in Uganda, with $6.7 \%$ of adults living with HIV in Uganda. ${ }^{9}$ However, its accurate diagnosis was rare in the late 1990s and the early 2000, and with minimal or no attention paid to psychiatric complications of HIV at the time, ${ }^{10}$ thus, more deaths occurred in 2002.
Heart attack (20\%), the most common cause of mortality in our study, is a common effect of metabolic disease (hypertension, diabetes, weight gain) and adverse effects of chronic antipsychotic use. ${ }^{11}$ Metabolic disease and other chronic medical conditions are common among patients and are implicated in their reduced lifespan and mortality compared to the general population. ${ }^{11-15}$ These conditions put most patients at risk of premature death through heart attack and hypoglycemia, among others, if poorly controlled during admission. These conditions are due to patients associated with risky lifestyles such as substance use, obesity, physical inactivity, risky sexual practices, poor nutrition, and use of psychiatric medications. ${ }^{11,16-19}$ Despite the increased risk to medical conditions, they are rarely diagnosed and managed adequately because fewer patients' visits are made to other physicians, few consultations to physicians, and if done, most of their symptoms are misinterpreted as somatic symptoms. ${ }^{20,21}$ They also rarely undergo a complete physical examination by their primary physicians, who mainly deal with mental health issues. $^{22}$

In this study, the majority of the causes of death are unknown. A finding that points to commonly observed causes of death, such as suicide..$^{4,23-26}$ Many admitted patients resort to suicide due to their experience of traumatic symptoms or shortcut to end suffering from their symptoms. ${ }^{24,27}$ One study in Israel reported a high mortality rate among admitted young (18 to 44 years) people with mental disorders linked mainly to suicide. ${ }^{23}$ Despite only two individuals having previous suicide attempts, suicide is common among patients with mood disorders and psychosis ${ }^{24,28}$ - the majority of the studied population. Previous studies also shown that most suicide-related deaths among patients with mental illness occur at night. ${ }^{29,30}$ In our study, most patients $(53.3 \%)$ died in the afternoon. However, our study had a small sample, and suicide was not among the reported causes of mortality to make any association between the time of death and suicide. The unknown causes of death may also be due to the complication of epilepsy - status epilepticus, accidents, suicide, and sudden unexpected death. ${ }^{31-33}$

There has been at least one death every year since 2000 due to various causes. An increased continuous review of patients by clinicians, a proven method that significantly lowers mortality, ${ }^{34}$ should be emphasised. Frequent patient reviews per day contribute to the timely detection of lifethreatening conditions such as hypoglycemia and appropriate management, which reduces mortality risk. In 
addition, regular patient reviews increase patient adherence to medication, which accelerates recovery. ${ }^{34-37}$ Thus, significantly lowering the chances of poor patientdoctor relationships which leads to delays in noticing dangerous signs and symptoms. ${ }^{34,35}$ Another way of preventing death among psychiatric patients is through to manage the risk of commonly occurring noncommunicable diseases (diabetes, hypertension, CVDs, and related heart attack) by providing and supporting services that increase healthy behaviours such as increased physical activities, healthy diet, and reducing/cessation of use of substances of addiction. ${ }^{11,13}$

\section{Limitations}

First, this was a retrospective chart review with data extracted from patients' medical charts; thus, the choice of study variables was contingent on the data available. Second, the patients sampled in the current study were from a single health facility; therefore, the findings may not be generalizable to other psychiatric facilities in the country. Finally, the sample of the charts reviewed was too small to draw generalizable conclusions.

\section{Conclusion}

The majority of the causes of mortality were unknown. The most common cause of mortality was heart attack, a common effect of metabolic disease and chronic antipsychotic use. Mortality audits are warranted for every deceased patient to identify possible causes in order to develop strategic interventions for mortality prevention.

\section{Ethical Considerations}

This study was conducted in accordance with the Declaration of Helsinki.

\section{Acknowledgment}

Annet Mutayomba, Department of Psychiatry Mbarara Regional Referral Hospital, retrieved the records.

\section{Author Contributions}

All authors made substantial contributions to conception and design, acquisition of data, or analysis and interpretation of data; took part in drafting the article or revising it critically for important intellectual content; agreed to submit to the current journal; gave final approval of the version to be published; and agreed to be accountable for all aspects of the work.

\section{Funding}

The authors declare that the study did not receive any financial support to support the compilation of this report or conducting the study.

\section{Disclosure}

The authors declare that they have no conflicts of interest.

\section{References}

1. Walker ER, McGee RE, Druss BG. Mortality in mental disorders and global disease burden implications: a systematic review and meta-analysis. JAMA Psychiatry. 2015;72(4):334-341. doi:10.1001/ jamapsychiatry.2014.2502

2. Crump C, Ioannidis JP, Sundquist K, Winkleby MA, Sundquist J. Mortality in persons with mental disorders is substantially overestimated using inpatient psychiatric diagnoses. J Psychiatr Res. 2013;47 (10):1298-1303. doi:10.1016/j.jpsychires.2013.05.034

3. Gale CR, Batty GD, Osborn DP, Tynelius P, Whitley E, Rasmussen F. Association of mental disorders in early adulthood and later psychiatric hospital admissions and mortality in a cohort study of more than 1 million men. Arch Gen Psychiatry. 2012;69(8):823-831. doi:10.1001/archgenpsychiatry.2011.2000

4. Firth J, Siddiqi N, Koyanagi A, et al. The Lancet Psychiatry Commission: a blueprint for protecting physical health in people with mental illness. Lancet Psychiatry. 2019;6(8):675-712.

5. Raedler TJ. Cardiovascular aspects of antipsychotics. Curr Opin Psychiatry. 2010;23(6):574-581. doi:10.1097/YCO.0b013e32833f46c9

6. Tsoi DT, Porwal M, Webster AC. Interventions for smoking cessation and reduction in individuals with schizophrenia. Cochrane Database Syst Rev. 2013;2.

7. Colton CW, Manderscheid RW. PEER REVIEWED: congruencies in increased mortality rates, years of potential life lost, and causes of death among public mental health clients in eight states. Prev Chronic Dis. 2006;3(2).

8. Goodell S, Druss BG, Walker ER, Mat MJ. Mental Disorders and Medical Comorbidity. Robert Wood Johnson Foundation; 2011:2.

9. Dickson-Gomez J, Twaibu W, Christenson E, et al. Injection and sexual risk among people who use or inject drugs in Kampala, Uganda: an exploratory qualitative study. PLoS One. 2020;15(4): e0231969. doi:10.1371/journal.pone.0231969

10. Su JA, Tsai CS, Hung TH, Chou SY. Change in accuracy of recognizing psychiatric disorders by non-psychiatric physicians: five-year data from a psychiatric consultation-liaison service. Psychiatry Clin Neurosci. 2011;65(7):618-623. doi:10.1111/j.1440-1819.2011.02272.x

11. Mwebe H, Roberts D. Risk of cardiovascular disease in people taking psychotropic medication: a literature review. Br J Ment Health Nurs. 2019;8(3):136-144. doi:10.12968/bjmh.2018.0033

12. Agaba DC, Migisha R, Katamba G, Ashaba S. Cardio-metabolic abnormalities among patients with severe mental illness at a Regional Referral Hospital in southwestern Uganda. PLoS One. 2020;15(7):e0235956. doi:10.1371/journal.pone.0235956

13. Agaba DC, Migisha R, Lugobe HM, Katamba G, Ashaba S. A 10 -year risk of cardiovascular disease among patients with severe mental illness at Mbarara Regional Referral Hospital, Southwestern Uganda. Biomed Res Int. 2020;2020:1-6. doi:10.1155/2020/2508751

14. Trifirò G, Verhamme KM, Ziere G, Caputi AP, Ch Stricker BH, Sturkenboom MC. All-cause mortality associated with atypical and typical antipsychotics in demented outpatients. Pharmacoepidemiol Drug Saf. 2007;16(5):538-544. doi:10.1002/pds.1334

15. Weinmann S, Read J, Aderhold V. Influence of antipsychotics on mortality in schizophrenia: systematic review. Schizophr Res. 2009;113(1):1-11. doi:10.1016/j.schres.2009.05.018 
16. Suvisaari J, Partti K, Perälä J, et al. Mortality and its determinants in people with psychotic disorder. Psychosom Med. 2013;75(1):60-67. doi:10.1097/PSY.0b013e31827ad512

17. Simon GE, Stewart C, Yarborough BJ, et al. Mortality rates after the first diagnosis of psychotic disorder in adolescents and young adults. JAMA Psychiatry. 2018;75(3):254-260. doi:10.1001/jamapsychiatry. 2017.4437

18. Singh SM, Surendran I, Jain S, et al. The prevalence of non-communicable disease risk factors in community-living patients with psychiatric disorders: a study from North India. Asian J Psychiatr. 2019;41:23-27. doi:10.1016/j.ajp.2019.03.004

19. Vancampfort D, Probst M, Basangwa D, et al. Adherence to physical activity recommendations and physical and mental health risk in people with severe mental illness in Uganda. Psychiatry Res. 2018;260:236-240. doi:10.1016/j.psychres.2017. 11.067

20. Rukundo ZG, Musisi S, Nakasujja N. Psychiatric morbidity among physically ill patients in a Ugandan Regional Referral Hospital. Afr Health Sci. 2013;13(1):87-93. doi:10.4314/ahs. v13i1.13

21. Klonoff EA, Landrine H. Preventing Misdiagnosis of Women: A Guide to Physical Disorders That Have Psychiatric Symptoms. Vol. 1. Sage; 1997.

22. De Hert M, Cohen DAN, Bobes J, et al. Physical illness in patients with severe mental disorders. II. Barriers to care, monitoring and treatment guidelines, plus recommendations at the system and individual level. World Psychiatry. 2011;10(2):138. doi:10.1002/j.20515545.2011.tb00036.x

23. Hakial Z, Stein N, Pugachova I, Levav I. The mortality risk among persons with psychiatric hospitalizations. Isr J Psychiatry Relat Sci. 2011;48(4):230.

24. Madsen T, Erlangsen A, Hjorthøj C, Nordentoft M. High suicide rates during psychiatric inpatient stay and shortly after discharge. Acta Psychiatr Scand. 2020;142(5):355-365. doi:10.1111/acps. 13221

25. Meyfroidt N, Wyckaert S, Bouckaert F, Wampers M, Mazereel V, Bruffaerts R. Suicide in Belgian psychiatric inpatients. A matched case-control study in a Belgian teaching hospital. Arch Psychiatr Nurs. 2020;34(2):8-13. doi:10.1016/j.apnu.2019.12.004

26. Kaggwa MM, Muwanguzi M, Nduhuura E. et al. Suicide among Ugandan university students: evidence from media reports for 2010-2020. BJPsych Int. 2021:1-4. doi:10.1192/ bji. 2021.13
27. Anyayo L, Ashaba S, Kaggwa MM, Maling S, Nakimuli-Mpungu E. Health-related quality of life among patients with bipolar disorder in rural southwestern Uganda: a hospital based cross sectional study. Health Qual Life Outcomes. 2021;19(1):1-8. doi:10.1186/s12955021-01729-5

28. Kaggwa MM, Nuwamanya S, Ashaba S, Rukundo GZ, Harms S. An adolescent's use of veterinary medicines: a case report exploring addiction. J Psychoactive Drugs. 2021;1-6. doi:10.1080/ 02791072.2021 .1873466

29. Fernandes SN, Zuckerman E, Miranda R, Baroni A. When night falls fast: sleep and suicidal behavior among adolescents and young adults. Child Adolesc Psychiatr Clin N Am. 2021;30(1):269-282. doi:10.1016/j.chc.2020.08.009

30. Tubbs AS, Perlis ML, Basner $M$, et al. Relationship of nocturnal wakefulness to suicide risk across months and methods of suicide. J Clin Psychiatry. 2020;81(2). doi:10.4088/ JCP. $19 \mathrm{~m} 12964$

31. Devinsky O. Sudden, unexpected death in epilepsy. $N$ Engl J Med. 2011;365(19):1801-1811. doi:10.1056/NEJMra1010481

32. Fukuchi T, Kanemoto K, Kato M, et al. Death in epilepsy with special attention to suicide cases. Epilepsy Res. 2002;51 (3):233-236. doi:10.1016/S0920-1211(02)00151-1

33. Maguire M, Singh J, Marson A. Epilepsy and psychosis: a practical approach. Pract Neurol. 2018;18(2):106-114. doi:10.1136/practneurol-2017-001775

34. Gray DJP, Sidaway-Lee K, White E, Thorne A, Evans PH. Continuity of care with doctors - a matter of life and death? A systematic review of continuity of care and mortality. BMJ Open. 2018;8(6):e021161. doi:10.1136/bmjopen-2017-021161

35. Chen $\mathrm{CC}$, Tseng $\mathrm{CH}$, Cheng SH. Continuity of care, medication adherence, and health care outcomes among patients with newly diagnosed type 2 diabetes: a longitudinal analysis. Med Care. 2013;51(3):231-237. doi:10.1097/MLR.0b013e31827da5b9

36. Hoertel N, Limosin F, Leleu H. Poor longitudinal continuity of care is associated with an increased mortality rate among patients with mental disorders: results from the French National Health Insurance Reimbursement Database. Eur Psychiatry. 2014;29(6):358-364. doi:10.1016/j.eurpsy.2013.12.001

37. Kreyenbuhl J, Nossel IR, Dixon LB. Disengagement from mental health treatment among individuals with schizophrenia and strategies for facilitating connections to care: a review of the literature. Schizophr Bull. 2009;35(4):696-703. doi:10.1093/schbul/sbp046
Clinical Audit

\section{Publish your work in this journal}

Clinical Audit is an international, peer-reviewed, open access journal focusing on the processes and outcomes of clinical audit in any area of healthcare. All aspects of patient care are addressed within the journal and practitioners from all disciplines are invited to submit their work. Areas covered include: Publication of audits; How an audit has changed practice; Practical tips on how to do audits and to

Submit your manuscript here: https://www.dovepress.com/clinical-audit-journal avoid pitfalls; How audits have changed patient care; Calls and justifications for new audits. The manuscript management system is completely online and includes a very quick and fair peer-review system, which is all easy to use. Visit http://www.dovepress.com/ testimonials.php to read real quotes from published authors. 